\title{
Towards sustainable re-construction systems: from waste ruins to eco-efficient buildings
}

\author{
Alexandra Del Castillo Llamosas(D), Shoeib Faraji Abdolmaleki* (1D, and Pastora M. Bello Bugallo@ \\ Department of Chemical Engineering, Universidade de Santiago de Compostela, Av. Lope Gómez de Marzoa s/n, 15782 Santiago \\ de Compostela, Spain
}

Received: 7 July 2021 / Accepted: 7 January 2022

\begin{abstract}
Building reconstruction projects are mainly motivated by social factors, without a deep evaluation of the Best Available Techniques. The main aim of this work is to analyze the advantages of defining sustainable retrofitted buildings, previously building the edifice, by using methodologies towards sustainable systems. A real re-constructed building is considered as a case study. Three scenarios are investigated to analyze its sustainability, including the waste ruins of the old building (Scenario 1), the current re-constructed building (Scenario 2), and a hypothetical sustainable retrofitted building (Scenario 3). Firstly, the current energy consumption is studied including heating flow through walls (thermal bridges and condensation risk) as well as operational costs. Secondly, a new scenario is proposed adding passive solutions to this existing building, to improve its energy efficiency; also, energy consumption and costs of the refurbishment are analyzed. Results show that Scenario 1 leads to a bad image of a city involving the environment and social fields. Scenario 2 entails expensive operational costs. On the other hand, Scenario 3 results in approximately $90 \%$ of cost savings in heating energy demand, which would be traduced on high economic savings. Taken into account not only economic factors but environmental and social ones, it can be concluded that it is more sustainable and profitable constructing an efficient building from the beginning by using waste ruins and simulation software despite refurbishing a re-built edifice.
\end{abstract}

\section{Introduction}

Nowadays, most of the discussions about the meaning of sustainability are focused on the triple bottom line (TBL) which deals with the positive results regarding economic, environmental, and social dimensions [1]. However, governance as a policymaker influences the rate and direction of socio-technical change towards sustainability [2], so governments take a relevant role.

The European Union (EU) is committed to reducing greenhouse gas emissions to 80-95\% below 1990 levels by 2050. Scenarios presented in the "roadmap for moving to a competitive low carbon economy in 2050" [3] suggest that the task of developing post-2020 strategies becomes urgent. All scenarios explained on the EU roadmap show that electricity will almost double its role in final energy demand to $36-39 \%$ in 2050 . Therefore, EU leaders agreed to reduce the EU's projected energy consumption reducing $40 \%$ of greenhouse gas emissions compared to 1990, reaching a share of at least $32 \%$ in renewable energy, and increasing

\footnotetext{
* e-mail: shoeib.faraji@rai.usc.es
}

energy efficiency at least $32.5 \%$ [4]. Two main strategies can be highlighted for transitioning to low carbon cities: shifting from fossil fuels to cleaner energy and reducing urban energy consumption [5].

The construction sector in the $\mathrm{EU}$ is the highest producer of waste compared with other economic sectors [6], producing globally $30 \%$ of solid waste, use $40 \%$ of raw materials, accounting for $40 \%$ of energy use, and is $16 \%$ of total water withdrawals [7-9]. Buildings are dynamic systems, being relevant to consider not only the proper activity in the use of a building (with the typical inputs and outputs), but also the activities in the stages of edifice construction, demolition, and others such as re-construction. To perform a complete analysis of the energy efficiency, the good management of its wastes on these stages must be also included.

To achieve a nearly zero energy building, it becomes necessary to understand the work's limitations: if it is a new edifice or an existing one. There are a wide variety of solutions depending on the age of the edifice situations, like those explained by Chwieduk [10] Retrofitting existing buildings promoting a more energy-efficient level can potentially result in national energy-savings [11] reducing 


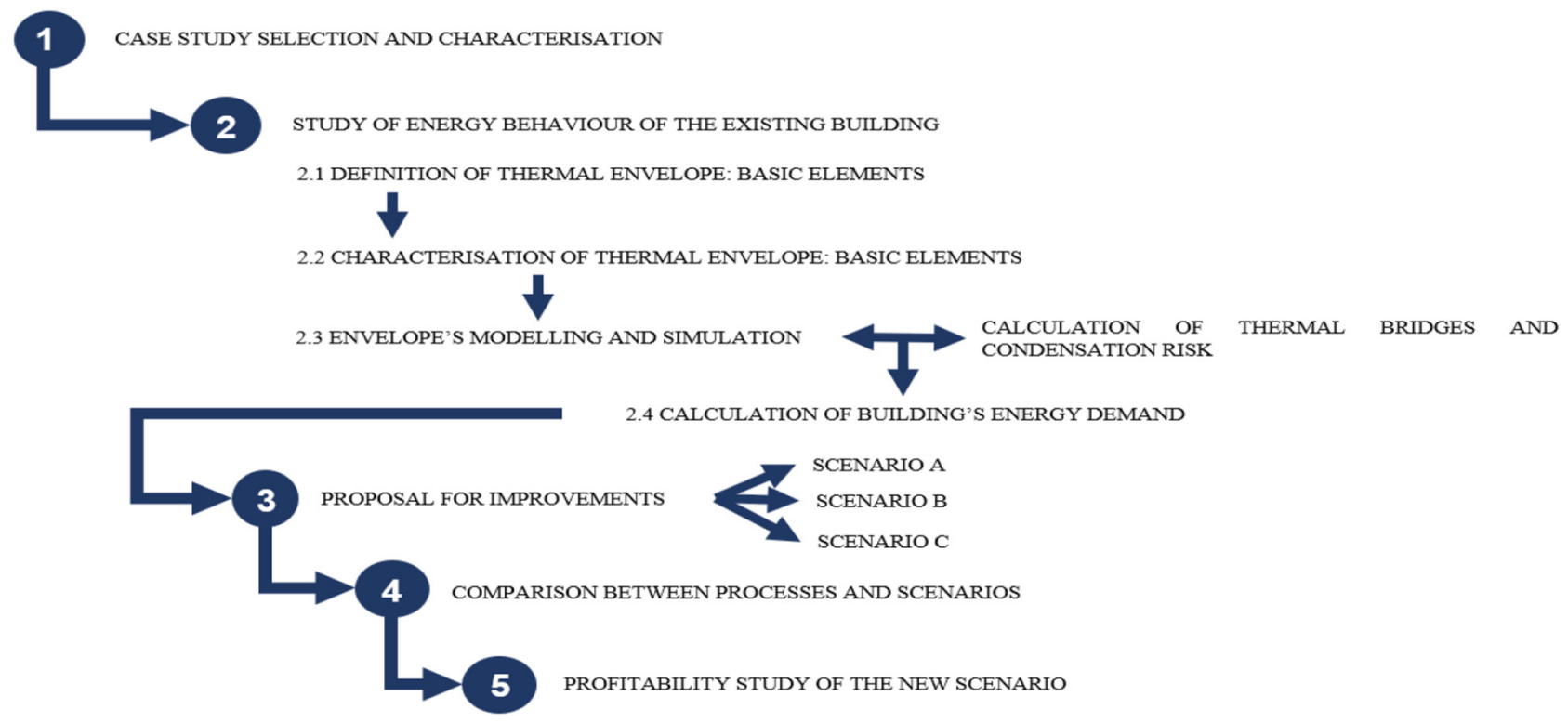

Fig. 1. Methodology.

$\mathrm{CO}_{2}$ emissions and the use of resources, as well as affecting positively socio-economic aspects [12]. Implementation of the Best Available Techniques (BAT), such as passive and energy saving technologies is a fundamental way for improving the building energy efficiency, which includes advanced edifice envelopes, passive heating/cooling, and thermal energy storage [13-16].

To measure the thermal performance of a building's envelope, it is commonly followed the thermal insulation standards, and the Overall Thermal Transfer Value (OTTV) [16]. There exist located areas on the building structure where the heat flow is different in comparison with adjacent areas, where temperature between inside and outside is different; these elements are called thermal bridges. The energy losses incurred by a linear thermal bridge are quantified by the linear thermal transmittance $(\psi)$ and measured in $(\mathrm{W} / \mathrm{mK})$. Also, punctual thermal bridges can be taken into account [17]. In general, thermal bridges would result in higher energy use for heating and cooling and discomfort due to cold surfaces, even deriving also on mould growth and its associated health concerns. Recently, many authors are developing studies focused on this humidity issue by using new technologies and/or simulation programs, such as the use of infrared thermography for detection of moisture sources in inside walls of buildings [18]; the study of a rulebased system as to determine the durability of moisture in building envelopes [19]; or the evaluation of highly insulated walls to bio-deterioration [20]. However, the relation between thermal bridges, different construction materials, and European building certifications has not yet been studied acutely by using steady simulation software based on a non-residential building as a case study.

The main aim of the present work is to propose a methodology for analyzing the sustainability of a case study based on a real non-residential retrofitted building, where the re-construction project was motivated by social factors (usual practice in last decades), without a deep evaluation of the BAT. Thus, it is demonstrated the advantages of eco-design by defining sustainable retrofitted buildings using methodologies towards sustainable systems $[21,22]$ previously building the edifice. Three new scenarios are proposed to achieve the most suitable one to redesign the edifice to ensure the achievement of a high energy efficiency level to fulfill the compliance of European 2050 requirements. This paramount objective is carried out including at the study thermal building's envelope simulation, the calculation of thermal bridges including condensation risks, the energy consumption simulation taking into account all different rooms with their different occupants, in-situ thermography, and a comparison between two European standards based on energy efficiency in buildings (Swiss and Spanish ones).

\section{Methodology}

A re-constructed building located in Ourense (northwest Spain) is considered a case study. Three scenarios have been considered to analyze its sustainability, including the waste ruins of the old building (Scenario 1), the current re-constructed building (Scenario 2), and a defined hypothetic sustainable retrofitted building (Scenario 3). Firstly, the energy consumption is studied including heating flow through walls (thermal bridges) and operational costs of the existing building (reconstructed from another building ruins) analyzed. Secondly, a new scenario is proposed adding passive solutions to this existing building, to improve its energy efficiency to achieve a near-zero energy building; also, energy consumption and costs of the refurbishment are analyzed.

The methodology followed to perform this project is divided into the following steps (Fig. 1):

Case study selection and characterization: A real edifice is selected as a case study and it is characterized based on its history and current use, in which processes and scenarios are identified. 


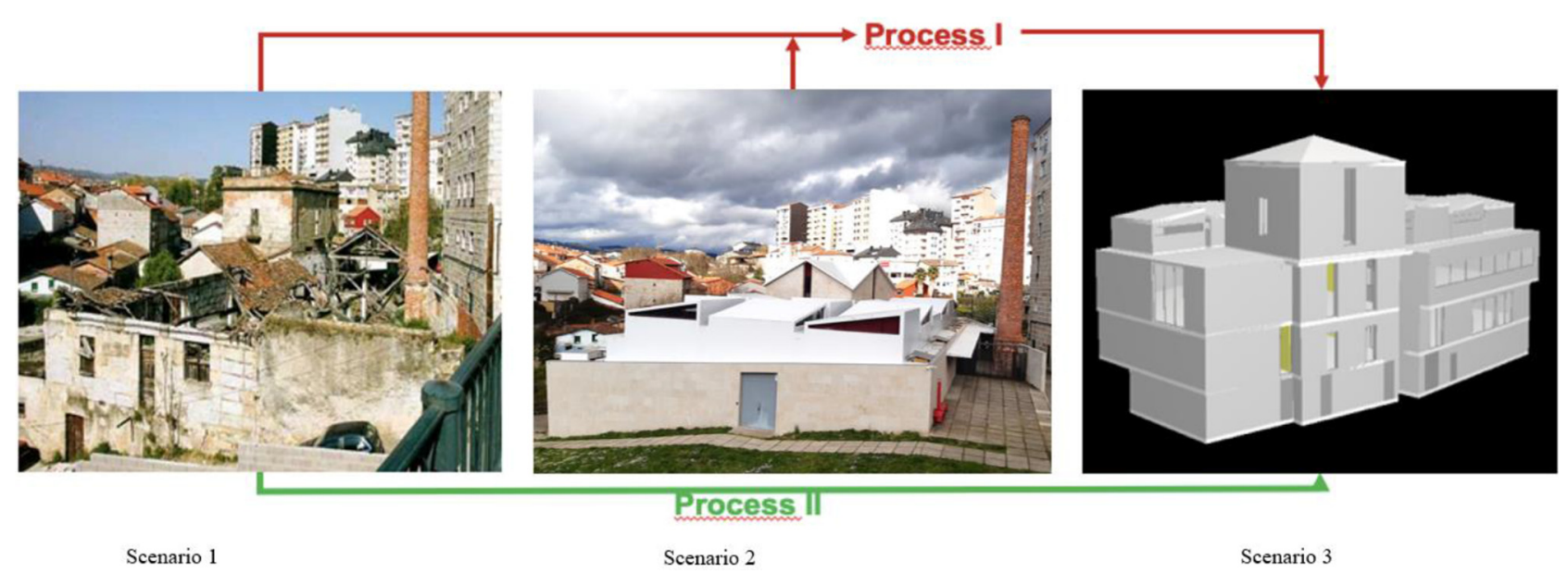

Fig. 2. Process and scenarios scheme.

Study of energy behavior of existing building: The thermal envelope of the existing building is defined and characterized taking into account the orientation of all floors, roofs, and facades; their slope and material composition are also taken into account. A software selection is employed for modeling and simulating the thermal envelope. Furthermore, thermal bridges, as well as their condensation risk are calculated. An in-situ thermographic study is performed to compare with simulation results. Finally, taking into account the real energy consumption of the building and simulation results, the building's energy demand is calculated. Results are imported to the official Spanish software for energy certification of buildings.

Proposal for improvements: Taking the existing scenario as a basis, three new scenarios are proposed and defined to achieve a higher energy efficiency level.

Comparison between processes and scenarios: Processes and scenarios are defined and compared.

Profitability study of new scenario: Operational costs are studied to analyze the profitability of the best scenario.

\section{Case study selection and characterization}

Ourense is located in the northwest of Spain and it is well known because of the historic utilization of natural sources for its development. This city exploits its thermal resources from antiquity to the present day on a wide variety of areas. These days, Ourense has improved its electric and heating installations in many public buildings by using natural resources such as thermal springs and other renewable energy sources. For example, swimming pool from the public sports hall "Los Remedios", in which water is heated by using indirectly the thermal energy from a hot spring with a heat exchanger. Ourense City Council promoting energy efficiency and investing in new projects. Therefore, this study is proposed the idea of work with "La Molinera" as a case study. This building was a flour manufacturing and storage building. After years of production the edifice was abandoned (which defines Scenario 1: old building waste ruins). In 2011, Ourense's Council decided to rebuild a new public edifice by reusing many of its ruins
(Scenario 2). Nowadays this four-floor building is a Digital Social Innovation Centre where many workshops are developed based on new technologies, social media, and electronic science.

\subsection{Energy performance}

Energy performance certification is a policy instrument for governments in decreasing the energy footprint of building [23]. There are many building certifications worldwide, with different developers and key figures Table 1.

The Technical Edification Code (TEC) [24] published in 2007 and modified in 2013, aims at the particular issue of energy saving in buildings in Spain [25] the Royal Decree $235 / 2013$ [26] is the one associated with Energetic Certification in Buildings. In the report entitled implementation of the EPDB in Spain [27] that is explained the calculation methodology of the Energy Performance Certificate (EPC derived from Energetic Certification in Buildings). This calculation must be performed through the official software Unified Tool Lider-Calener (in Spanish Herramienta Unificada Lider-Calener, HULC).

\section{Study of the energy behavior of the existing building}

\subsection{Definition of the thermal envelope (the basic elements)}

First of all, Scenario 2 is defined. Building's envelope is characterized; understanding this envelope as all the elements of the exterior of the edifice including walls, floors, and roofs in contact with the exterior, against underground or against those unheated surfaces which do not belong to the building itself. The software Auto-CAD is selected for La Molinera's characterization, as all plans provided by the council were created on this software.

Energetic Surface Reference (E.S.R.) refers to the sum of all the floor surfaces included in the thermal envelope that needs to be heated or conditioned.

This E.S.R. is defined on software selected using floor plans as a basis Table 2. The surface of floors, facades, 
Table 1. Six main building certifications gathered at the Market study for a voluntary common EU certification scheme for the energy performance of non-residential buildings [28].

\begin{tabular}{lll}
\hline Certification system & Developer & Key figures \\
\hline LEED & US Green Building Council & - US +30 countries \\
& $(1993)$ & - Over 7 000 projects, over $140 \mathrm{~km}^{2}$ \\
& & - Sustainability rating \\
DGNB system & German Sustainable & -25 countries \\
& Building Council & -13 different building types \\
& & - Around 50 criteria assessed \\
PassivHaus & Germany (1988) & - Over 30000 buildings \\
& & - Over 15 countries \\
BREEAM & BRE (UK, 1988) & - Over 50 countries \\
& & -8 National Scheme Operators \\
& & - Over 250 000 buildings \\
HQE & Association pour la Haute & - Primarily used in France \\
& Qualité Environnementale & -14 targets for environmental quality \\
& (France, 2005) & -4 different building types \\
Minergie & Switzerland & - Core markets: France, Italy, Germany and the USA \\
& & (8 countries) \\
& & -13 building types, primarily used in the residential \\
& & - Energy and indoor comfort-focused \\
\hline
\end{tabular}

Table 2. E.R.S. calculation.

\begin{tabular}{|c|c|c|c|c|}
\hline & Element & High & Partial surface & Volume \\
\hline Cellar/Basement 1 & Floor I & $2,60 \mathrm{~m}$ & $269,01 \mathrm{~m}^{2}$ & $699,43 \mathrm{~m}^{3}$ \\
\hline Cellar/Basement 2 & Floor II & $3,15 \mathrm{~m}$ & $575,69 \mathrm{~m}^{2}$ & $1.813,42 \mathrm{~m}^{3}$ \\
\hline Ground floor & Floor III & $3,55 \mathrm{~m}$ & $768,69 \mathrm{~m}^{2}$ & $2.728,85 \mathrm{~m}^{3}$ \\
\hline First flat & Floor IV & $5,13 \mathrm{~m}$ & $84,81 \mathrm{~m}^{2}$ & $435,08 \mathrm{~m}^{3}$ \\
\hline TOTAL & - & - & $1.698,20 \mathrm{~m}^{2}$ & $5.676,77 \mathrm{~m}^{3}$ \\
\hline
\end{tabular}

and roofs are delimited and drawn on Auto-CAD using both floors and elevated plans. Facades are classified by their orientation and material composition following the information acquired by construction section plans, and they are named with correlative numbers from 1 to 28 .

\subsection{Characterization of the thermal envelope (the basic elements)}

A database is created using Microsoft Excel with information about floors, facades, and roofs defined and classified by their orientation, slope, and material composition based on information taken from constructive section plans. This information of Scenario 2 is treated on a spreadsheet to calculate the total surface and volume of the building, the area of all the basic elements belonging to the envelope (floors, roofs, and facades) as well as how many square meters of each wall are occupied by windows and doors Tables $3-5$.

\subsection{Envelope's modeling and simulation}

Simulation tools can help in the prediction of failures and design of equipment [28]. This work is based on a steady model because the general thermal behavior of the building is studied considering the less favorable conditions with an exterior temperature of about $-3.3{ }^{\circ} \mathrm{C}$. Although, modeling could have been performed by a dynamic model as some authors did $[16,22]$. 
Table 3. Floors, roofs and facadés surface calculation.

\begin{tabular}{|c|c|c|c|c|c|}
\hline & Element & Boundary conditions & Gross area & Non-heating surface & Heating surface \\
\hline \multirow{43}{*}{ TOTAL } & Floor I & $\mathrm{AE}$ & $575.83 \mathrm{~m}^{2}$ & $306.82 \mathrm{~m}^{2}$ & $269.01 \mathrm{~m}^{2}$ \\
\hline & Floor II & $\mathrm{AE}$ & $192.23 \mathrm{~m}^{2}$ & $105.80 \mathrm{~m}^{2}$ & $86.43 \mathrm{~m}^{2}$ \\
\hline & & & $960.29 \mathrm{~m}^{2}$ & $518.42 \mathrm{~m}^{2}$ & $441.87 \mathrm{~m}^{2}$ \\
\hline & Element & Boundary conditions & Gross Area & Net Area & Orientation \\
\hline & Roof I & $\mathrm{AE}$ & $14.05 \mathrm{~m}^{2}$ & $28.10 \mathrm{~m}^{2}$ & $43^{\circ} \mathrm{NE}$ \\
\hline & Roof II & $\mathrm{AE}$ & $14.05 \mathrm{~m}^{2}$ & $28.10 \mathrm{~m}^{2}$ & $321^{\circ} \mathrm{NW}$ \\
\hline & Roof III & $\mathrm{AE}$ & $14.05 \mathrm{~m}^{2}$ & $28.10 \mathrm{~m}^{2}$ & $141^{\circ} \mathrm{SE}$ \\
\hline & Roof IV & $\mathrm{AE}$ & $14.05 \mathrm{~m}^{2}$ & $28.10 \mathrm{~m}^{2}$ & $230^{\circ} \mathrm{SW}$ \\
\hline & Roof V & $\mathrm{AE}$ & $29.16 \mathrm{~m}^{2}$ & $116.64 \mathrm{~m}^{2}$ & $310^{\circ} \mathrm{NW}$ \\
\hline & Roof VI & $\mathrm{AE}$ & $29.16 \mathrm{~m}^{2}$ & $87.48 \mathrm{~m}^{2}$ & $40^{\circ} \mathrm{NE}$ \\
\hline & Roof VII & $\mathrm{AE}$ & $29.16 \mathrm{~m}^{2}$ & $58.32 \mathrm{~m}^{2}$ & $130^{\circ} \mathrm{SE}$ \\
\hline & Roof VIII & $\mathrm{AE}$ & $29.16 \mathrm{~m}^{2}$ & $87.48 \mathrm{~m}^{2}$ & $220^{\circ} \mathrm{SW}$ \\
\hline & Roof IX & $\mathrm{AE}$ & $39.12 \mathrm{~m}^{2}$ & $39.12 \mathrm{~m}^{2}$ & $321^{\circ} \mathrm{NW}$ \\
\hline & Roof X & $\mathrm{AE}$ & $332.83 \mathrm{~m}^{2}$ & $332.83 \mathrm{~m}^{2}$ & $0^{\circ}-$ \\
\hline & & & & $834.27 \mathrm{~m}^{2}$ & \\
\hline & Facade I & $\mathrm{AU}$ & $85.97 \mathrm{~m}^{2}$ & $85.97 \mathrm{~m}^{2}$ & $220^{\circ} \mathrm{SW}$ \\
\hline & Facade II & $\mathrm{AE}$ & $89.00 \mathrm{~m}^{2}$ & $86.80 \mathrm{~m}^{2}$ & $220^{\circ} \mathrm{SW}$ \\
\hline & Facade III & $\mathrm{AE}$ & $5.86 \mathrm{~m}^{2}$ & $3.61 \mathrm{~m}^{2}$ & $220^{\circ} \mathrm{SW}$ \\
\hline & Facade IV & $\mathrm{AE}$ & $109.08 \mathrm{~m}^{2}$ & $81.58 \mathrm{~m}^{2}$ & $220^{\circ} \mathrm{SW}$ \\
\hline & Facade V & $\mathrm{AU}$ & $80.00 \mathrm{~m}^{2}$ & $62.73 \mathrm{~m}^{2}$ & $321^{\circ} \mathrm{NW}$ \\
\hline & Facade VI & $\mathrm{AU}$ & $15.67 \mathrm{~m}^{2}$ & $15.67 \mathrm{~m}^{2}$ & $321^{\circ} \mathrm{NW}$ \\
\hline & Facade VII & $\mathrm{AU}$ & $15.58 \mathrm{~m}^{2}$ & $15.58 \mathrm{~m}^{2}$ & $321^{\circ} \mathrm{NW}$ \\
\hline & Facade VIII & $\mathrm{AU}$ & $7.71 \mathrm{~m}^{2}$ & $7.71 \mathrm{~m}^{2}$ & $310^{\circ} \mathrm{NW}$ \\
\hline & Facade IX & $\mathrm{AU}$ & $53.80 \mathrm{~m}^{2}$ & $41.78 \mathrm{~m}^{2}$ & $321^{\circ} \mathrm{NW}$ \\
\hline & Facade X & $\mathrm{AE}$ & $133.38 \mathrm{~m}^{2}$ & $110.59 \mathrm{~m}^{2}$ & $321^{\circ} \mathrm{NW}$ \\
\hline & Facade XI & $\mathrm{AE}$ & $10.64 \mathrm{~m}^{2}$ & $0.64 \mathrm{~m}^{2}$ & $321^{\circ} \mathrm{NW}$ \\
\hline & Facade XII & $\mathrm{AE}$ & $32.27 \mathrm{~m}^{2}$ & $27.23 \mathrm{~m}^{2}$ & $310^{\circ} \mathrm{NW}$ \\
\hline & Facade XIII & $\mathrm{AE}$ & $64.00 \mathrm{~m}^{2}$ & $57.68 \mathrm{~m}^{2}$ & $310^{\circ} \mathrm{NW}$ \\
\hline & Facade XIV & $\mathrm{AE}$ & $58.00 \mathrm{~m}^{2}$ & $33.96 \mathrm{~m}^{2}$ & $310^{\circ} \mathrm{NW}$ \\
\hline & Facade XV & $\mathrm{AE}$ & $66.97 \mathrm{~m}^{2}$ & $51.97 \mathrm{~m}^{2}$ & $310^{\circ} \mathrm{NW}$ \\
\hline & Facade XVI & $\mathrm{AU}$ & $215.62 \mathrm{~m}^{2}$ & $215.62 \mathrm{~m}^{2}$ & $130^{\circ} \mathrm{SE}$ \\
\hline & Facade XVII & $\mathrm{AE}$ & $77.61 \mathrm{~m}^{2}$ & $68.11 \mathrm{~m}^{2}$ & $130^{\circ} \mathrm{SE}$ \\
\hline & Facade XVIII & $\mathrm{AE}$ & $48.10 \mathrm{~m}^{2}$ & $48.16 \mathrm{~m}^{2}$ & $130^{\circ} \mathrm{SE}$ \\
\hline & Facade XIX & $\mathrm{AE}$ & $95.92 \mathrm{~m}^{2}$ & $80.21 \mathrm{~m}^{2}$ & $130^{\circ} \mathrm{SE}$ \\
\hline & Facade XX & $\mathrm{AE}$ & $51.35 \mathrm{~m}^{2}$ & $44.68 \mathrm{~m}^{2}$ & $130^{\circ} \mathrm{SE}$ \\
\hline & Facade XXI & $\mathrm{AU}$ & $31.51 \mathrm{~m}^{2}$ & $31.51 \mathrm{~m}^{2}$ & $43^{\circ} \mathrm{NE}$ \\
\hline & Facade XXII & $\mathrm{AU}$ & $14.96 \mathrm{~m}^{2}$ & $14.96 \mathrm{~m}^{2}$ & $43^{\circ} \mathrm{NE}$ \\
\hline & Facade XIII & $\mathrm{AU}$ & $2.00 \mathrm{~m}^{2}$ & $0.66 \mathrm{~m}^{2}$ & $43^{\circ} \mathrm{NE}$ \\
\hline & Facade XIV & $\mathrm{AE}$ & $60.52 \mathrm{~m}^{2}$ & $60.52 \mathrm{~m}^{2}$ & $43^{\circ} \mathrm{NE}$ \\
\hline & Facade XV & $\mathrm{AE}$ & $52.65 \mathrm{~m}^{2}$ & $38.21 \mathrm{~m}^{2}$ & $43^{\circ} \mathrm{NE}$ \\
\hline & Facade XVI & $\mathrm{AE}$ & $56.55 \mathrm{~m}^{2}$ & $49.88 \mathrm{~m}^{2}$ & $43^{\circ} \mathrm{NE}$ \\
\hline & Facade XXVII & $\mathrm{AE}$ & $49.59 \mathrm{~m}^{2}$ & $34.59 \mathrm{~m}^{2}$ & $43^{\circ} \mathrm{NE}$ \\
\hline & Facade XXVIII & $\mathrm{AE}$ & $46.92 \mathrm{~m}^{2}$ & $43.28 \mathrm{~m}^{2}$ & $40^{\circ} \mathrm{NE}^{\circ}$ \\
\hline
\end{tabular}

AE: Against Exterior; AU: Against Underground; NE: North-East; NW: North-West; SE: South-East; SW: South-West; -: without any orientation. 
Table 4. Multi-layer proposals for Scenario 3.

\begin{tabular}{|c|c|c|c|c|c|c|}
\hline \multicolumn{7}{|c|}{ Proposal "a" } \\
\hline$\overline{\text { Material }}$ & $\begin{array}{l}\text { Thermal } \\
\text { conductivity } \\
\lambda(\mathrm{W} / \mathrm{mK})\end{array}$ & $\begin{array}{l}\text { Width } \\
\text { (cm) }\end{array}$ & & Material & $\begin{array}{l}\text { Thermal } \\
\text { conductivity } \\
\lambda(\mathrm{W} / \mathrm{mK})\end{array}$ & $\begin{array}{l}\text { Width } \\
(\mathrm{cm})\end{array}$ \\
\hline Rock wool & 0.028 & 8 & & Rock wool & 0.028 & 12 \\
\hline Vapor layer & 0.02 & 0.2 & & Vapor layer & 0.02 & 0.2 \\
\hline $\begin{array}{l}\text { Gypsum } \\
\text { plasterboard }\end{array}$ & 0.21 & 2.5 & & $\begin{array}{l}\text { Gypsum } \\
\text { plasterboard }\end{array}$ & 0.21 & 2.5 \\
\hline
\end{tabular}

\begin{tabular}{|c|c|c|c|c|c|c|}
\hline \multicolumn{7}{|c|}{ Proposal "b" } \\
\hline & Facades & & Layers of materials & & and ceilings & \\
\hline Material & $\begin{array}{l}\text { Thermal } \\
\text { conductivity } \\
\lambda(\mathrm{W} / \mathrm{mK})\end{array}$ & $\begin{array}{l}\text { Width } \\
(\mathrm{cm})\end{array}$ & & Material & $\begin{array}{l}\text { Thermal } \\
\text { conductivity } \\
\lambda(\mathrm{W} / \mathrm{mK})\end{array}$ & $\begin{array}{l}\text { Width } \\
(\mathrm{cm})\end{array}$ \\
\hline Rock wool & 0.028 & 12 & & Rock wool & 0.028 & 12 \\
\hline $\begin{array}{l}\text { Vapor } \\
\text { layer }\end{array}$ & 0.02 & 0.2 & & Vapour layer & 0.02 & 0.2 \\
\hline $\begin{array}{l}\text { Gypsum } \\
\text { plasterboard }\end{array}$ & 0.21 & 2.5 & & $\begin{array}{l}\text { Gypsum } \\
\text { plasterboard }\end{array}$ & 0.21 & 2.5 \\
\hline
\end{tabular}

\begin{tabular}{|c|c|c|c|c|c|c|}
\hline \multicolumn{7}{|c|}{ Proposal "c"" } \\
\hline & Facades & & Layers of materials & & and ceilings & \\
\hline Material & $\begin{array}{l}\text { Thermal } \\
\text { conductivity } \\
\lambda(\mathrm{W} / \mathrm{mK})\end{array}$ & $\begin{array}{l}\text { Width } \\
(\mathrm{cm})\end{array}$ & & Material & $\begin{array}{l}\text { Thermal } \\
\text { conductivity } \\
\lambda(\mathrm{W} / \mathrm{mK})\end{array}$ & $\begin{array}{l}\text { Width } \\
(\mathrm{cm})\end{array}$ \\
\hline PUR & 0.024 & 14 & & PUR & 0.024 & 14 \\
\hline $\begin{array}{l}\text { Vapor } \\
\text { layer }\end{array}$ & 0.02 & 0.2 & . & $\begin{array}{l}\text { Vapor } \\
\text { layer }\end{array}$ & 0.02 & 0.2 \\
\hline $\begin{array}{l}\text { Gypsum } \\
\text { plasterboard }\end{array}$ & 0.21 & 2.5 & & $\begin{array}{l}\text { Gypsum } \\
\text { plasterboard }\end{array}$ & 0.21 & 2.5 \\
\hline
\end{tabular}

BREEAM, LEED, DGNB, HQE, and Passivhaus are worldwide known and studied building energy certifications, as most certified buildings in the EU are under these five leading schemes [29]. Minergie, from Switzerland, is selected because it considers costs as an additional variable - no cost may exceed more than $10 \%$ of a conventional building cost. Due to this fact, the software selected for model and simulation is Lesosai, because in addition to permit the easy creation of a database (floors, facades, and roofs taking into account thermal bridges values). It is commonly used for designing sustainable buildings, as it complies with the SIA 380/1 [30], mandatory for every new building project in Switzerland.
Thus, materials of each floor, facade, and roof are added to Lesosai following the compositions defined on constructive section plans. It is also considering windows and doors on each corresponding wall in which supposed that all floors belonging to the envelope have the same composition: suspended floor with $25 \mathrm{~cm}$ of reinforced concrete with $1 \%$ steel.

For analyzing the thermal performance, thermal transmittance values (U-values) are calculated following thermal insulation standards. Thermal bridges are modeled, simulated, and calculated. Condensation risks are also taken into account. "THERM" software was used for modeling and simulating these thermal bridges, due to its 
Table 5. Calculation of thermal bridges (Scenario 2 and Scenario 3 proposals "b" and "c").

\begin{tabular}{llll}
\hline & Thermal bridge & $\Psi(\mathrm{W} / \mathrm{MK})$ & Condensation risk \\
\hline SCENARIO 2 & TB1 & 0.5209 & None \\
& TB 2 & 0.6658 & None \\
& TB 2 B) & 1.1065 & None \\
TB 3 & 0.4547 & None \\
TB 3 B) & 0.817 & Yes \\
& & None \\
SCENARIO 3 PROPOSAL "B" & TB 0.1 & 0.872 & None \\
& TB 0.2 & 0.267 & None \\
TB 0.2 B) & 0.249 & Yes \\
TB 0.3 & 1.1238 & None \\
TB 0.3 B) & 0.5504 & None \\
TB 1 & -1.6531 & None \\
TB 2 & 0.6516 & None \\
TB 2 B) & 0.7939 & None \\
& TB 0.1 & -0.1407 & None \\
TB 0.2 & 0.0646 & None \\
TB 0.2 B) & 0.934 & None \\
TB 0.3 & TB 0.3 B) & 1.7929 & None \\
TB1 & 0.3239 & None \\
TB2 & 0.472 & None \\
\hline
\end{tabular}

TB: Thermal Bridge.

feasibility [31] and fast way for simulating. After the THERM simulation, a previous calculation was performed:

$$
\emptyset=\text { Uvaluet } \cdot \Delta T t \cdot L t
$$

where $\phi$ is Information of the thermal bridge $(\mathrm{W} / \mathrm{m})$, Uvalue $_{t}$ : $U$-value exported directly from THERM simulation $\left(\mathrm{W} / \mathrm{m}^{2} \mathrm{~K}\right), \Delta T_{t}$ : Temperature difference exported from THERM simulation $(K)$, and $\mathrm{L}_{\mathrm{t}}$ : Length exported from THERM simulation $(m)$.

As many other thermal bridge calculations were performed [32], the final value of the linear thermal bridge $(\Psi$-value, measured in $\mathrm{W} / \mathrm{mK})$ is calculated, without taking into account punctual thermal ones. Next formula shows the calculation:

$$
\Psi=\emptyset-\text { Uvalue }_{1} \cdot \Delta T_{1} \cdot L_{1}-\mathrm{Uvalue}_{2} \cdot \Delta T_{2} \cdot L_{2}
$$

Assuming that sub-number 1 refers to the first multilayer section, and sub-number 2 to the second one forming the thermal bridge:

Where $\Psi$ is Thermal bridge value $(\mathrm{W} / \mathrm{mK})$, $\phi$ : Information of the thermal bridge $(\mathrm{W} / \mathrm{m}), \mathrm{U}$-value ${ }_{1,2}$ : U-value exported from Lesosai software, of the elements (walls, facades, roofs, floors) which conform the thermal bridge object of study, $\Delta T_{1,2:}$ Difference of temperature between the boundary conditions of the elements object of study $(K)$, and $L_{1,2}$ is the length of the element object of study $(m)$.

The sea level altitude of Ourense, the critical month for moulds growth, and $f_{\text {Rsi }}$ value from the SIA 180:2014 Protection thermique, protection contre l'humidité et climat intérieur dans les bâtiments [33] (taking into account its correction on 2015 Correctif C1 à la norme SIA 180:2014) are the calculation basis for condensation risks. Next formula is used for calculation:

$$
\mathrm{fRsi}, \min =\frac{\theta \mathrm{si}, \min -\theta \mathrm{a}, \mathrm{e}, \min }{\theta_{\mathrm{i}}-a, e, \min }
$$

where $f_{\text {Rsi,min }}$ is Minimal Temperature's Factor acceptable [33], $\theta_{\mathrm{a}, \mathrm{e}}, \mathrm{min}$ is Minimal Outdoor Temperature in Ourense ([34], measured in $(K)), i$ is the Indoor Air Temperature in La Molinera $(K)$, and $\theta_{s i}$ is Air temperature of indoor surface in La Molinera $(\mathrm{K})$.

The final value of the thermal bridge $(\psi)$ measured in $\mathrm{W} / \mathrm{mK}$ is upload on Lesosai on the Inventory of the corresponding facade to complete the model and to simulate the existing building (Scenario 2).

\subsection{Calculation of building's energy demand}

After having studied the thermal envelope, this existing building (Scenario 2) is modeled and simulated on CATE 
DMELECT, a calculation program of thermal loads in buildings based on graphic design. This software was selected because it is commonly used in Spain while all data can be easily exported to HULC (Unified Tool Lider-Calener, in Spanish Herramienta Unficada Lider-Calener), official software recommended by CTE [24] (Technical Code of Edification, in Spanish Código Técnico de Edificación). Moreover, many authors have selected DMELECT to develop their investigation studies in this country [35-37].

Walls are drawn using information imported by floor plans provided by "La Molinera". Every enclosure is defined with its constructive characteristics and properties of the floor, ceiling, heating-cooling system, illumination, and occupation. It must be highlighted that occupant's presence, as well as opening and closing of windows, have an important impact on energy that a building needs $[38,39]$. Thus, windows and doors are created taking into account its detailed surface as well as its transmittance and proportion glass / frame. Once carpentry was placed on each corresponding wall, the calculation was performed. This simulation was exported to HULC (official Spanish software). This software calculates if there exists any non-compliance with guidelines HE- 1 and HE- 0 of the CTE specification, and also exports a certification about building's energy efficiency in terms of $\mathrm{CO}_{2}$ and nonrenewable primary energy consumption.

Infrared thermography (IR) can be used to analyze heat energy losses through the building envelope. This IR employs an infrared detector and an imaging system that convert the surfaces' emissive power into a temperature pattern [40]. Thus, Thermo-graphic Camera Testo 875 Thermal Figurer Wärmebildkamera is used to measure energy losses of walls in situ. With this camera, the inside and outside walls temperatures were measured in degrees Celsius $\left({ }^{\circ} \mathrm{C}\right)$ to understand how the heat flow was working on Scenario 2 and to validate the thermal bridge calculation.

\subsection{Proposal for improvements}

Eco-design in the building sector can be defined as "those tools which minimize the inherent environmental impact of a construction", taking into account energy saving, human health, or biodiversity protection [41].

Due to the many benefits provided by passive solutions $[22,42,43]$, the main improvement is about to enhance the thermal refurbishment of La Molinera. Thus, the retrofitted building starts the roadmap to becoming an RBE (responsive building envelope), which relies on integrated technologies combining passive, active, and cognitive control strategies [44].

Facades, floors, and roofs are modeled and simulated on Lesosai (as Best Available Technique) adding some new isolation materials (Tab. 4). Thermal bridges based on new wall composition were simulated on THERM and calculated (Tab. 5). Proposals of Scenario 3 are simulated on Lesosai, to ensure that refurbishment of construction elements compiled with Minergie Standard, with all its already studied restrictive limitations [45]. Thus, three new proposals are studied to select the optimal one to define Scenario 3.

\subsubsection{Comparison between processes and scenarios}

The optimal proposal was finally called Scenario 3. Later, two processes were compared (Fig. 1):

- From Scenario 1 to Scenario 3 including scenario 2.

- Building Scenario 3 directly from Scenario 1 by using simulation software towards energy efficiency as BAT.

\subsubsection{Profitability study of the new scenario}

The budget of performing the best proposals is studied. This one is calculated using software PRESTO, which permits the calculation of the project operation cost by using a database. The database selected was CYPE online software [46], because it provides current existing materials and stuff Spanish costs.

\section{Results and discussion}

\subsection{Study of the energy behavior of the existing building}

The study of the existing thermal bridges (Scenario 1) shows that there exist many important thermal bridges (Tab. 5): TB2 b) with a value of $1.10(\mathrm{~W} / \mathrm{mK})$, and TB $3 \mathrm{~b})$ with $0.817(\mathrm{~W} / \mathrm{mK})$, both located on granite facade against the exterior. If condensation risk is analyzed, this second thermal bridge could be susceptible to having condensation. In-situ thermography validated the thermal bridges and condensation risks calculation. These values are added to corresponding facades on Lesosai and the model is completed. Checking the Energy Flow Analysis (Sankey diagram) exported as a result of Lesosai simulation (Figure 3 (left)), it can be observed that currently, "La Molinera" demands $250,6 \mathrm{kWh} / \mathrm{m}^{2}$ when the limit value of Minergie is about $31.9 \mathrm{kWh} / \mathrm{m}^{2}$. So, the existing version of the building does not meet Minergie standards.

For the purpose of obtain its Energy Certification by CTE [24] (Technical Edification Code; in Spanish Código Técnico de la Edificación), the edifice is modelled on CATE DMELECT and exported to HULC program. The report from this software shows that "La Molinera" has a C qualification on non-renewable primary energy demand. This qualification means that this edifice has not huge energy consumption, but it could improve its energy efficiency. If heating demand is analyzed, it can be observed a big difference between heating and cooling demand, exporting $\mathrm{F}$ certification as a result. It can be supposed that this qualification must come from high energy consumption in winter because of cold outside temperatures. Thus, it can be verified that the existing version of "La Molinera" is not a sustainable edifice if all the elements that energy consumption involves are analyzed. Even though, its electricity bill and thermography were studied taking into account that climatic data plays an important role in the assessment of building behavior [47].

On the other side, temperature increases in summer (from June to August), so that could be the reason why in spring and autumn (March-May, and September-November) energy consumption decreases, increasing in summer due to cooling demand. Checking La Molinera's energy 


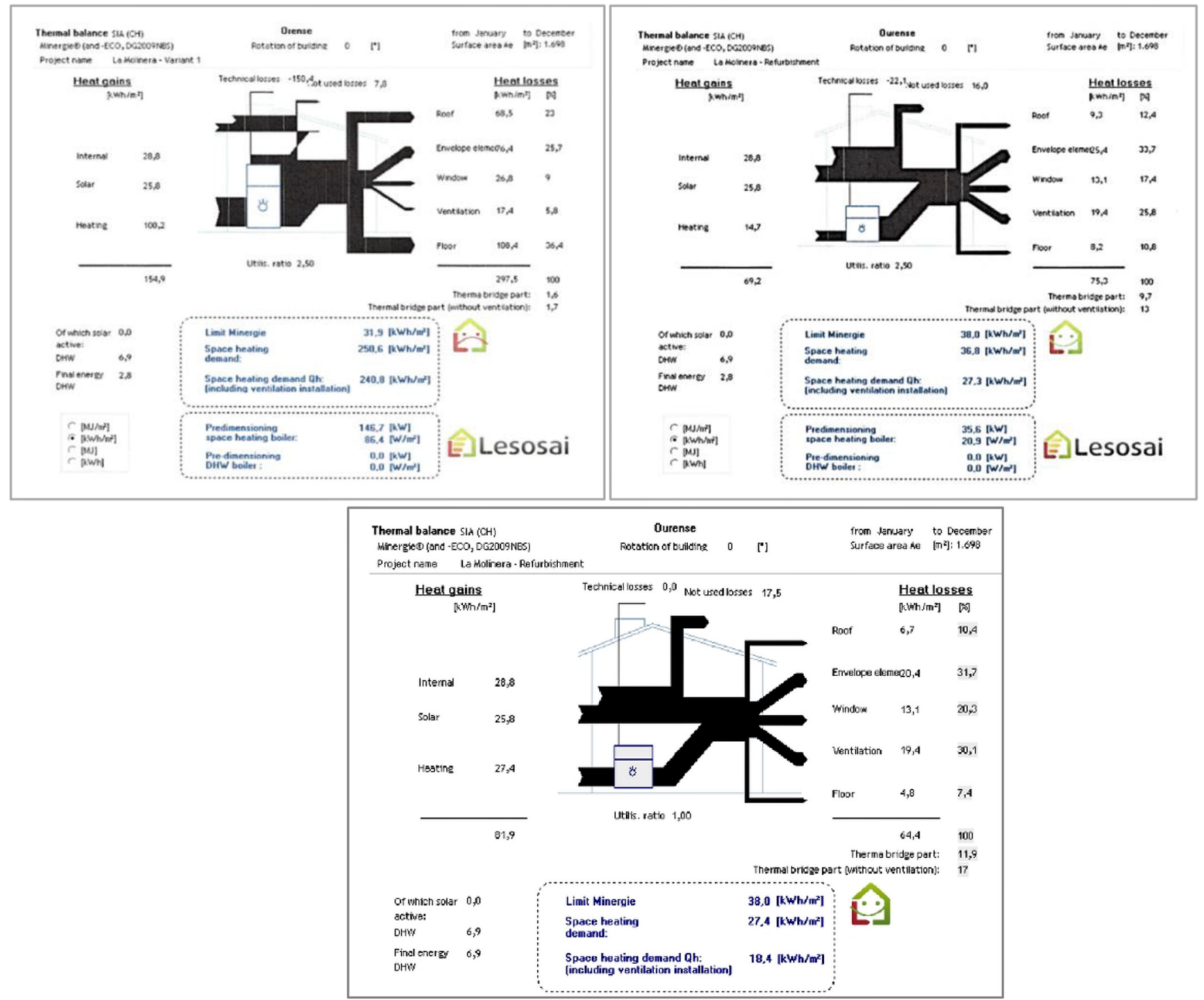

Fig. 3. Sankey diagram of scenario 2 (left), scenario 3b (right), and scenario 3c (down).

demand in winter, and images exported from Checking AEMET (Association of Spanish Meteorology) [34] information, in winter (from December to February) temperatures descend in Ourense, so rising in electricity consumption during this season (observed on electricity bill) must come from heating demand. After having analyzed the in-situ thermography study, it was observed that energy consumption rocket due to the high thermal transfer between outside and inside. So, the F qualification on heating demand resulted from the Energy Certification previously studied is justified.

\subsection{Proposal for improvements and scenario building}

The air source heat pump (ASHP) integrated into the existing building is based on aero-thermal energy. Many authors defend that important reductions in heating and cooling demand can be achieved using a combination of wellestablished technologies such as glazing, shading, insulation, and natural ventilation [48]. Due to that fact, the improvement on heating and cooling demand proposed is just to recommend to building's users the natural ventilation of the edifice. This natural ventilation refers to the removal of air from an indoor space without using mechanical systems (opening windows and/or doors). However, existing glass windows with a $U$-value of $1.2\left(\mathrm{~W} / \mathrm{m}^{2} \mathrm{~K}\right)$ are replaced for glazing with $0.8\left(\mathrm{~W} / \mathrm{m}^{2} \mathrm{~K}\right)$ on new proposals to reduce heat losses assuring more comfortable enclosures.

Checking the Sankey diagram derived from Lesosai simulation of Scenario 2 (Fig. 3 (left)) it can be observed that the main reason for heating energy consumption is heat losses through the floor. Because of that, it was proposed an interior thermal refurbishment of envelope elements, especially on floors belonging to the envelope. As pointed previously by some authors [49] providing corrections on thermal bridges is not imposed on the Spanish legislation, but they were corrected to fulfill the Minergie Standard. It was decided to isolate the interior of the building for two reasons: firstly, 
Table 6. Thermal Bridges and Condensation risks

\begin{tabular}{lll}
\hline Thermal bridges & $\Psi(\mathrm{W} / \mathrm{MK})$ & Condensation risks \\
\hline TB 0.1 & 0.872 & None \\
TB 0.2 & 0.267 & None \\
TB 0.2 B $)$ & 0.249 & None \\
TB 0.3 & 1.1238 & None \\
TB 0.3 B) & 0.5504 & Yes \\
TB 1 & -1.6531 & None \\
TB 2 & 0.6516 & None \\
TB 2 B) & 0.7939 & None \\
\hline
\end{tabular}

with the main objective of maintaining the aesthetic of facades, and in second place, because of the large economic investment that it would entail.

Different proposals (a, b, and c) to define Scenario 3 are collected in Table 4 . These new proposals are simulated on Lesosai. Ideal walls should have a U-value between 0.15 and $0.20\left(\mathrm{~W} / \mathrm{m}^{2} \mathrm{~K}\right)$. Following this indication, the proposal "a" based on adding a rock-wool layer, was ruled out because of the huge U-value achieved $\left(0.2557 \mathrm{~W} / \mathrm{m}^{2} \mathrm{~K}\right)$. Proposal "b" with the same construction material layer but higher width, achieved a more favorable $U$-value $\left(0.1991 \mathrm{~W} / \mathrm{m}^{2} \mathrm{~K}\right)$.

This proposal "b" resulted in new thermal bridges, which are modeled and simulated on THERM, and finally calculated. Results from thermal bridges as well as condensation risk calculation can be observed in Table 6 . Many thermal bridges have decreased compared with an existing building (Scenario 2), such as TB $2 \mathrm{~b}$ ) from 1.10 to $0.79\left(\mathrm{~W} / \mathrm{m}^{2} \mathrm{~K}\right)$. On the other side, it exists condensation risk on thermal bridge $0.3 \mathrm{~b}$ ), located in basement 1 , between the suspended floor and a wall against the interior.

Values from proposal "b" are added to Lesosai. Results show that this proposal does complain with Minergie Standard, although close to limit values with a heating demand of $36.8 \mathrm{kWh} / \mathrm{m}^{2}$ when it should not exceed $38 \mathrm{kWh} / \mathrm{m}^{2}$. Sankey diagram of proposal "b" can be observed in Figure 3 (right). It is important to highlight the huge improvement in heat losses, especially on suspended floors. With this thermal isolation, the heating demand has decreased $213.8 \mathrm{kWh} / \mathrm{m}^{2}$, with subsequent economic savings and environmental benefits in terms of energy consumption. A DMELECT calculation of proposal "b" is performed and exported to HULC. Results show that energy efficiency increased, so this interior isolation resulted from a good solution to ensure a decline in energy demand.

To ensure a better Minergie Standard compliance with more distance from limit values, it is proposed a new third version of "La Molinera", proposal "c", adding a PUR layer instead of rock-wool. Thermal bridges with this new composition are simulated and new condensation risks are calculated Table 5.

Comparing these results with the ones derived from proposal "b", it is eliminated the probable condensation risk on Thermal Bridge $0.3 \mathrm{~b}$ ). Many U-values were also improved, such as TB 0.2 with $0,267 \mathrm{~W} / \mathrm{m}^{2} \mathrm{~K}$ on rock wool version, decreasing until $0.0646\left(\mathrm{~W} / \mathrm{m}^{2} \mathrm{~K}\right)$ on PUR version; or TB 2 from $0.6515\left(\mathrm{~W} / \mathrm{m}^{2} \mathrm{~K}\right)$ to $0.2535\left(\mathrm{~W} / \mathrm{m}^{2} \mathrm{~K}\right)$. This new refurbishment of proposal "c" is added to Lesosai, and results show a heating demand of about $27.4\left(\mathrm{kWh} / \mathrm{m}^{2}\right)$, complaining with Minergie (Fig. 3 down). After having simulated this third proposal on DMELECT and exporting it to HULC, it is observed that energy efficiency highly increased compared with proposal "b".

Thus, these two last proposals ("b" and "c") of Scenario 3 do meet the objectives of energy efficiency from Spanish Regulations (CTE) and also, they are in compliance with the restrictive Minergie Standard. Because of that, the operational cost of both valid proposals is calculated to finally define a profitable Scenario 3.

\subsection{Calculation of refurbishment budget}

Budget's calculation is performed using software PRESTO, based on a data basis downloaded from CYPE [46]. New isolation materials and new carpentry prices were taken into account as well as the labor cost of construction and carpentry installation. Proposal "b" would have a cost of $93933.05 €$ while proposal "c" $65506.18 €$. The $28436.87 €$ of difference lies in the isolation material used: rock wool or PUR. Even though it is clear that rock wool is more expensive than PUR, the first one has also some complications in the construction phase, so it results in expensive stuff costs.

Analyzing all these results, it is concluded that the optimal version of Scenario 3 is the one where PUR is the thermal isolation material (proposal "c"). This proposal of Scenario 3 is chosen as the optimal because it is the most efficient solution for heating and cooling demand and global energy consumption of the building. Moreover, it is the most economical one.

So, the first process to analyze is from Scenario 1 to Scenario 3 including Scenario 2: the budget to perform this process was about to build the first edifice $1491114 €$ and to refurbish it as to achieve a sustainable building in compliance with Swiss Minergie Standards, which would cost $65506.18 €$. Thus, process 1 is traduced in approximately $1556620.85 €$.

The second process is from Scenario 1 directly to Scenario 3: the hypothetical budget for building a sustainable edifice directly from construction waste ruins would be about $1509860.25 €$.

\section{Conclusions}

Results show that even having construction ruins disposed at the street (Scenario 1) does not entail any expenditure, it is true that this scenario leads to a bad image of a city involving the environment and social fields. The second scenario (the existing building constructed with the old edifice ruins) adds a high value in society and environment to the city, but construction and refurbishment of the building as well as current electricity bills are traduced on expensive operational costs. On the other hand, the third scenario, even more 
environmentally and socially friendly, results in around 90\% of cost savings in heating energy demand, which would be traduced on high economic savings.

It was observed that in Spain there exists a potential for improvement in terms of energy efficiency in buildings. This can be demonstrated by developing methodologies that show that applying more restrictive Standards from other European countries could serve as a support to strengthen and improve our legislation.

For deeper investigation, the energy needs under untypical boundary conditions can be taken into account to complete even more the analysis of building energy performance resilience. Moreover, a detailed Material and Energy Flow Analysis (MEFA) can be performed based on Improvable Flows (IF) identified, for creating a BAT inventory [50].

After having carried out this study, taking into account not only economic factors but environmental social, and governmental ones, it can be concluded that it is more sustainable and profitable constructing an efficient building from the beginning (studying its energy behavior) and using waste ruins, despite of refurbishing a retrofitted one. Thus, the proposed methodology based on improvable flows and simulation software (as the best available technique) helps to develop a construction project towards sustainable construction systems. This methodology empowers the philosophy of circular economy in terms of well waste management by reusing edifice ruins, and buildings simulation, promoting eco-design thinking.

\section{Implementations and influences}

For the first time, this study proposes a methodology including all together: building's envelope simulation, calculation of thermal bridges and condensation risks, energy demand simulation taking into account all different rooms with their distinct occupants, thermography and comparison between two European standards based on energy efficiency in buildings (Swiss and Spanish ones). This methodology for sustainable retrofitting structures has been tested in a genuine case study, a public edifice with varying uses and occupations depending on the space, and 28 distinct types of facades, incorporating waste materials from an ancient building's ruins (Circular Economy perspective) that promotes the eco-design in construction by using the Best Available Techniques and passive solutions.

\section{Implementations and influences}

The highlights for the paper entitled "Towards sustainable re-construction systems: from waste ruins to eco-efficient buildings" are:-

-Real reconstructed building motivated by social factors as case study.-Modelling of thermal envelope, energy demand, thermal bridges and condensation risk.

-Energy demand and economic savings by Best Available Techniques and passive solutions.

-Eco-design for reconstructing in spite of refurbishing a re-built edifice, results more sustainable.
Acknowledgments. The authors would like to thank Jose Carlos Álvarez, from the company Alvtek S.L. for the advice received during the elaboration of the study.

\section{References}

1. L. Bartocci, C.J. Chiappetta, A.B. Lopes de Sousa, D. Kannan, Sustainability as a dynamic organizational capability: as systematic review and a future agenda toward a sustainable transition, J. Clean. Prod. 142, 308-322 (2017)

2. D.L. Edmondson, F. Kern, K.S. Rogge, The co-evolution of policy mixes and socio-technical systems: towards a conceptual framework of policy mix feedback in sustainability transitions, Res. Policy. 48, 103555 (2019)

3. European Commission, Energy Roadmap 2050. Luxembourg (2012)

4. European Commission, In-depth analysis in support on the COM (2018) 773: A Clean Planet for all - A European strategic long-term vision for a prosperous, modern, competitive and climate neutral economy (2018)

5. D.M. Kammen, D.A. Sunter, City-integrated renewable energy for urban sustainability, Science 325, 922-928 (2016)

6. P. Villoria Sáez, M.S. Osmani, A diagnosis of construction and demolition waste generation and recovery practice in the European Union, J. Clean. Prod. 241, 118400 (2019)

7. M.K. Nematchoua, S. Asadi, S. Reiter, A study of life cycle assessment in two old neighbourhoods in Belgium, Sustain. Cities Soc. 52, 101744 (2020)

8. S. Reiter, Life cycle assessment of buildings - a review, in ArcelorMittal International Network in Steel Construction, Sustainability Workshop and Third Plenary Meeting, Bruxelles, Belgique (2010)

9. B.A. Burgan, M.R. Sansom, Sustainable steel construction, J. Constr. Steel Res. 62, 1178-1183 (2006)

10. D.A. Chwieduk, Towards modern options of energy conservation in buildings, Renew. Energy. 101, 1194-1202 (2017)

11. K.N. Streicher, P. Padey, D. Parra; M.C. Bürer, M.K. Patel, Assessment of the current thermal performance level of the Swiss residential building stock: statistical analysis of energy performance certificates, Energy Build. 178, 360378 (2018)

12. R. Castaño-Rosa, J. Solís-Guzmán, M. Marrero, Energy poverty goes south? Understanding the costs of energy poverty with the index of vulnerable homes in Spain, Energy Res. Soc. Sci. 60, 101325 (2020)

13. B. Serra, P. Verdejo, A. Díaz, R. Merí, Assembling sustainable ideas: the construction process of the proposal SML system at the Solar Dechatlon Europe 2012, Energy Build. 83, 186-194 (2014)

14. X. Cao, X. Dai, J. Li, Building energy-consumption status worldwide and the estate-of-the-art technologies for zeroenergy buildings during the past decade, Energy Build. 128, 198-213 (2016)

15. U. Stritiha, V.V. Tyagib, R. Stropnika, H. Paksoyc, F. Haghighatd, M. Mastani Joybarid, Integration of passive PCM technologies for net-zero energy buildings, Sustain. Cities Soc. 41, 286-295 (2018)

16. S. Natephra, N. Yabuki, T. Fukuda, Optimizing the evaluation of building envelope design for thermal performance using a BIM-based overall thermal transfer value calculation, Build. Environ. 136, 128-145 (2018) 
17. T. Theodosiou, K. Tsikaloudaki, D. Bikas, Analysis of the thermal bridging effect on ventilated facades, Proc. Environ. Sci. 38, 397-404 (2017)

18. C. Firmino dos Santos, J.H. Aquino Rocha, Y. Vieira Póvoas, Use of infrared thermography for detection of moisture sources in internal walls of buildings, Ambiente Construído 19, 105-127 (2019)

19. P. Boudreaux, S. Pallin, G. Accawi, A. Desjarlais, R. Jackson, D. Senecal, A rule-based expert system applied to moisture durability of building envelopes, J. Build. Phys. 42, 416-437 (2018)

20. K. Gradeci, U. Berardi, B. Time, J. Köhler, Evaluating highly insulated walls to withstand biodterioration: a probabilisticbased methodology, Energy Build. 177, 112-124 (2018)

21. A.H. Wiberg, L. Georges, T.H. Dokka, M. Haase, B. Time, A.G. Lien, S. Mellegard, M. Maltha, A net zero emission concept analysis of a single-family house, Energy Build. 74, 101-110 (2014)

22. N. Soares, J.J. Costa, A.R. Gaspar, P. Santos, Review of passive PCM latent heat thermal energy storage systems towards buildings' energy efficiency, Energy Build. 59, 82-103 (2013)

23. L. Pastore, M. Andersen, Building energy certification versus user satisfaction with the indoor environment: findings from a multi-site post-occupancy evaluation (POE) in Switzerland, Build. Environ. 150, 60-74 (2019)

24. CTE, Technical Edification Code, in Spanish "Código Técnico de la Edificación" (2007)

25. J. García-Sanz-Calcedo, F. López-Rodríguez, Analysis on the performance of a high efficiency administrative building in Spain, Int. J. Green Energy. 14, 55-62 (2017)

26. Royal Decree, of Basic procedure of energetic certification in buildings, in Spanish "Procedimiento básico para la certificación energética de edificios" (2013)

27. EPBD, Implementation of the EPDB in Spain, 2010. Available at http://www.epbd-ca.org/Medias/Downloads/ CA_Book_Implementing_the_EPBD_Featuring_Coun try_Reports_2010.pdf (Accessèd on 03/12/2019)

28. Reference Document on Best Available Techniques for Energy Efficiency (2009)

29. European Commission, the Market study for a voluntary common European Union certification scheme for the energy performance of non-residential buildings (2014)

30. SIA 380-1, Thermal energy on buildings, in French, "L'energie thermique dans le bâtiment" (2001)

31. P.D. Ball, M. Despeisse, S. Evans, R.M. Greenough, S.B. Hope, R. Kerrigan, A. Levers, P. Lunt, V. Murray, M.R. Oates, L. Shao, T. Waltniel, A.J. Wright, Factory Modelling: Combining Energy Modelling for Buildings and Production Systems, Institute of Energy and Sustainable Development (2012)

32. H. Viot, A. Sempeya, M. Pauly, L. Mora, Comparison of different methods for calculating thermal bridges: application to wood-frame buildings, Build. Environ. 93, 339-348 (2015)

33. SIA 180, Protection thermique, protection contre l'humidité et climat intérieur dans les bâtiments, 2014

34. AEMET, (2017). Link: http://www.aemet.es/es/datos_a biertos/AEMET_OpenData [last view on 19/12/19]
35. V.J. Fernández-Membrive, X.B. Lastra-Bravo, A. TolónBecerra, Cost-benefit analysis of changes in energy in building technology in Southeast Spain, Energy Build. 103, 29-37 (2015)

36. J.L. Paredes Ortiz, Comparative study of specific software for calculation of industrial urbanisms instalations, Application of a case study in Spanish "Estudio comparative del software específico apra el cálculo de instalaciones de urganismo industrial. Aplicación a un caso concreto" (2008)

37. S. Benítez Martín, Study of applications of geothermal energy in Spain: practice case for cooling of a residential building in Spanish "Estudio de las aplicaciones de la energía geotérmica en España: caso práctico para climatización de una vivienda unifamiliar" (2011)

38. F. Haldi, D. Robinson, The impact of occupants behavior on building energy demand, J. Build. Perform. Simul. 4, 323338 (2011)

39. J. Li, Z.J. Yu, F. Haghighat, G. Zhang, Development and improvement of occupant behaviour models towards realistic building performance simulation: a review, Sustain. Cities Soc. 50, 101685 (2019)

40. I. Nardi, E. Lucchi, T. Rubeis, D. Ambrosini, Quantification of heat energy losses through the building envelope: a stateof-the-art analysis with critical and comprehensive review on infrared thermography, Build. Environ. 146, 190-205 (2018)

41. G. Lamé, Y. Leroy, B. Yannou, Ecodesign tools in the construction sector: Analyzing usage inadequacies with designers' needs, J. Clean. Prod. 148, 60-72 (2017)

42. S.B. Sadineni, S. Madala, R.F. Boehm, Passive building energy savings: a review of building envelope components, Renew. Sustain. Energy Rev. 15, 3617-3631 (2011)

43. P. Bevilacqua, D. Mazzeo, N. Arcuri, Thermal inertia assessment of an experimental extensive green roof in summer conditions, Build. Environ. 131, 264-276 (2018)

44. E. Taveres-Cachat, S. Grynning, J. Thomsen, S. Selkowitz, Responsive building envelope concepts in zero emission neighborhoods and smart cities - a roadmap to implementation, Build. Environ. 149, 446-457 (2019)

45. M. Hall, A. Geissler, B. Burger, Two years of experience with a net zero energy balance - analysis of the Swiss MINERGIE-A, Energy Proc. 48, 1282-1291 (2014)

46. CYPE, Construction prices generator, in Spanish "Generador de precios de la construcción CYPE", 2017. Available at: http:// www.generadordeprecios.info/ (Accessed on 12/07/2017)

47. G. Murano, D. Dirutigliano, V. Corrado, Improved procedure for the construction of a Typical Meteorological Year for assessing the energy need of a residential building, J. Build. Performance Simul. 13, 139-151 (2020)

48. A.M. Omer, Renewable building energy systems and passive human comfort solutions, Renew. Sustain. Energy Rev. 12, 1562-1587 (2008)

49. G. Evola, G. Margani, L. Marletta, Energy and cost evaluation of thermal bridge correction in Mediterranean climate, Energy Build. 43, 2385-2393 (2011)

50. M.T. Torres Rodríguez, L. Cristóbal Andrade, P.M. Bello Bugallo, J.J. Casares Long, Combining LCT tools for the optimization of an industrial process: material and energy flow analysis and best available techniques, J. Hazard. Mater. 192, 1705-1719 (2011)

Cite this article as: Alexandra Del Castillo Llamosas, Shoeib Faraji Abdolmaleki, Pastora M. Bello Bugallo, Towards sustainable re-construction systems: from waste ruins to eco-efficient buildings, Renew. Energy Environ. Sustain. 7, 12 (2022) 